\title{
THE INNER CONFLICT OF THE MAIN CHARACTER IN THE AVIATOR (2004) USING SIGMUND FREUD PERSPECTIVE
}

\author{
Cut Novita Srikandi, M. Hum \\ Lecturer of Muhammadiyah-University of Tangerang \\ Email: cutsrikandi@gmail.com
}

\begin{abstract}
This study aimed to analyze the inner conflict of the main character in the movie entitled The Aviator. The Aviator takes the life story of world aviation named Howard Hughes. Howard Hughes is a young millionaire, entrepreneur, and also a movie director. He succeed seize his ambition at 24 years old. Freud's psychoanalysis approach used in analyzing the main characters is experiencing growth or personality changes dynamically. Changes and developments in the main characters' personalities due to their inner conflicts are complicated. The main character is kept up haunted by inner conflict, anxiety, and helplessness facing reality outside itself. Inner conflicts triggered by the sequences of events in the past, directly and indirectly influence or change the personality of the character. The inner conflict was traced and understood by using the theory of Freud's psychoanalysis.
\end{abstract}

Key words: Inner Conflict, psychoanalysis, personality, main character, The Aviator

\section{A. INTRODUCTION}

\section{Background}

Literary work can be defined as the reflection of what happened in the society. The reflection can be the life problems, philosophy, and psychology. Refer to that matter, literary work can be understood through psychological aspect in the psychology science. Therefore, to understand a literary work not only based on substantive aspect, but also another aspect like psychology. The 
psychology concept introduced by Sigmund Freud. In this case, psychology is not all about the science of psychology, but a branch of personality theory.

Film is included in one of literary work in a form to be analyzed by psychoanalysis approach. As dreaming that has a piece of picture, film is able to create that piece of picture moves and produce a story. Hence, we can conclude that a film is the realization of dream. As Freud said that every dream needs to be interpreted, film too. The interpretation of film can be seen from the element that forming the film itself, either intrinsic element, or extrinsic element.

The Aviator (2004) is one of popular Hollywood film in 2004. This film was directed by Hollywood popular director named Martin Scorce and supported by famous actor named Leonardo di Caprio. This film takes the life story of world aviation, he is Howard Hughes. The story takes place in 1920 to 1947. Howard Hughes is a young millionaire, entrepreneur, and also a movie director. He succeed seize his ambition since his young age. At 24 years old, he had built USA Aviation business, stake out the aircraft, became famous director, and also movie producer that depleting big budget to get his lover who were the famous actress in that era, they are Katherine Hepburn and Ava Gardner. But then, in contrast with the success life of Howard Hughes, he had inner conflict that can be effect to his psychological. The inner conflict and psychological problem of Howard Hughes cannot be separated from his memories of the past with his mother. Howard Hughes's mother introduced him to the tenets and dogmas to little Howard, that afterward he bring to his life when he grows up. The extremely love to his mother makes Howard Hughed hold on the tenets and dogmas that has been given by his mother until he become adult.

Because of the close relationship this movie with psychoanalysis case, so psychoanalysis approach in literary work is proper to use to analyze the film entitled The Aviator. Because of that reason, the writer decides to take this film as psychoanalysis study in this research, entitled The Inner Conflict of Main Character in The Aviator (2004) Using Sigmund Freud Perspective.

In this research, the writer connects narrative elements and cinematographic elements in the film entitled 'The Aviator' with the principles dealing with psychoanalysis elements. The concept of psychoanalysis that told 
by Sigmund Freud in the beginning (1895 until 1905), that is human mind are consist of conscious, pre-conscious (Freud 1987: xiii). In his book, 'The Ego and The Id' (1923), Freud rearranged with another terminologies, that are id, ego, and superego as human personality structure. The Id is unconscious unsure, whereas ego and superego is conscious unsure. According to Hall, the three systems work dynamically; the intention is that the id, the ego, and the superego may affect each other, as well as the environment and the three systems that work inter-related.

\section{Theoretical Framework}

\section{Oedipus complex; The Theory}

To better understand and analyze Oedipus complex, we have to take a look at the base of Freudian psycho analysis. Freud starts his mission in the world of psychology with the treatment of hysteria which according to him was caused by sexual desire but unfortunately this was not acknowledged by his mentor Dr. Joseph Breuer under whose guidance Freud was learning about hysteria (Rahim, 2002 in Ahmed (2012). He strongly believed and popularized the idea of conscious versus unconscious mind. In his hypothesis, the conscious mind is what one is aware of at any particular moment like someone's present perceptions, memories, thoughts, fantasies, and feelings. Hence, preconscious mind is what closely work with the conscious mind or it is the memories that is not presently conscious but can be made conscious easily. According to Freud these two are the smallest parts of brain, the largest part is what he called the unconscious. In Freud's view this unconscious level of mind is the source of man's motivations such as desires for sex, food and so on. Furthermore, Freudian psychology is largely based on objects that are guided by needs; hunger, thirst, the avoidance of pain and sex. Boeree (2006) said that when everyone thought of male and female as roles determined by nature or God, he showed how much they depended on family dynamics. Hence, Freud's thoughts are ever supposed to be guided by desires. He believes that these desires are the fundamental factors of human life and psyche other than any 
spiritual and moral functions. According to Freud, among the objects organism is the prime one whose important part is nervous system which is known as id at beginning. This id transforms the needs of organism into motivational forces which Freud called wishes. Here there is a great contradiction regarding this id. Boeree (2006) said that the infant, in the Freudian view, is pure or nearly pure id.

Sigmund Freud introduced the term 'Oedipus complex' in his 'Interpretation of Dreams (1899). According to him, the concept is a desire for sexual involvement with the parent of the opposite sex, which produces a sense of competition with the parent of the same sex and a crucial stage in the normal developmental process (Freud, 1913). In a brief, Freud used the term to refer to a stage in the development of young boys. He assumed that in early development, around the age of five, young children wish to have their entire mother's love. Thus, jealousy causes them to resent and even unconsciously wish the death of their father. The term Oedipus complex was indeed named after the name of Greek mythical figure Oedipus who was the son of king Laius and queen Jocasta of Thebes, and finally killed his father and married his mother unconsciously which according to the belief of the writer and people of that time, was designed by fate (Safra in Ahmed (2012)). But, according to Sigmund Freud, the accidents or incidents in the life of Oedipus happened because of sexual complexity between Oedipus and his mother. And on the basis of this story he invented the concept Oedipus complex which he attributed to children of about the age of three to five. He views that all human behavior are motivated by sex or by the instincts, which in his opinion are the neurological representations of physical needs. He firstly referred to those as the life instincts which perpetuate the life of the individual, initially by motivating him or her to seek food and water, and secondly by motivating him or her to have sex. The motivational energy of these life instincts, the "oomph" that powers our psyches, he called libido, from the Latin word for "I desire" (Boeree, 2006). Freud's clinical experience led him to view sex as much more important in the dynamics of the psyche than other needs. We are, after all, social creatures, and sex is the most essential of social needs. Here, we have to 
remember that Freud put much more importance on sexual desire than any other thing.

\section{Research Methodology}

This study used a qualitative approach. Creswell (2008) revealed that qualitative research is oriented to exploration and understanding of a particular phenomenon or life problems. A qualitative approach was conducted using descriptive analysis to describe the facts in the film The Aviator. The next stage is to analyze and describe the main character and characterization of the film. For the next, describing psychological values that surround the life of the main character, a way to analyze and describe the object under study.

\section{B. FINDING AND DISCUSSION}

Research on the film The Aviator focuses on the main characters, namely Howard Hughes. Freud's psychoanalysis approach will be used in analyzing the main character; this approach is used by, among other reasons. That is because in this film the main character experiencing growth or personality changes dynamically. Changes and developments in the main characters' personalities due to their inner conflicts are complicated. The main character is kept up haunted by inner conflict, anxiety, and helplessness facing reality outside itself. Inner conflicts triggered by the sequences of events in the past, directly and indirectly influence or change the personality of the character. The inner conflict was traced and understood by using the theory of Freud's psychoanalysis. The following will discuss the causes and inner conflicts experienced by Howard Hughes.

The film begins with a scene of a mother was bathing a boy who was about nine years old. He is a small Howard. When soaping Howard, her mother gave her dogma that the outside world is evil, and it was not safe to be there. His mother is also constantly taught and asked Howard to spell the word "Quarantine". 

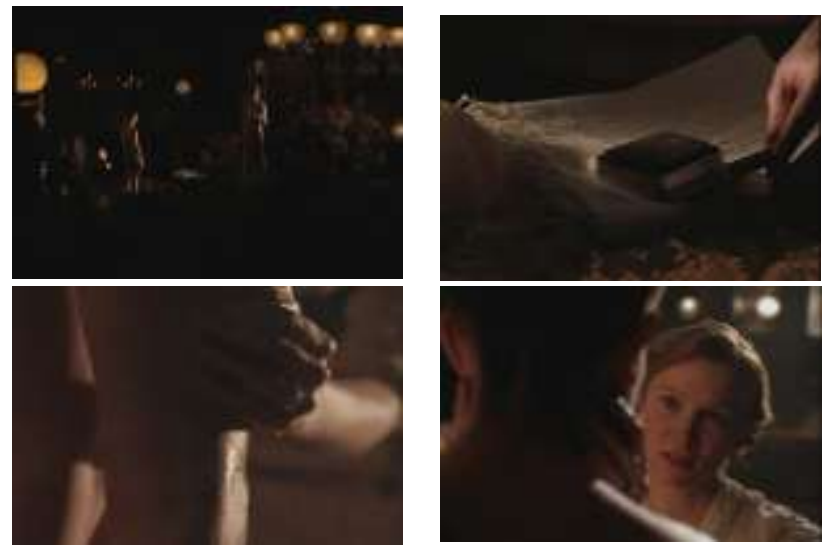

(Illustration I)

Minutes 00:00- 00:40

The picture above is part of the early scenes of the film opening. The first images taken by shooting in a long shot, Howard showed little naked on a bucket of water and a mother who was walking toward him. The second picture was taken with extreme close-up methods, namely by disclosing clearly soap in the box taken by the mother. The third picture shows the mother was rubbing the small Howard agency also taken extreme close-ups. And last, a picture describes a mother's face in close-up with Howard facing her.

This scene is a scene that is most important to know the psychological condition of Howard. Dogmas and teachings given by Howard's mother in this scene will affect the mental condition Howard in the future. The scene also shows that the presence of excessive closeness between mother and child. It seems clear in this scene that mothers are overprotective towards Howard's self that she did no exaggeration to protect her child, for example in the shower scene. Howard age, it is appropriate to conduct its own bathroom, but in the scene her mother suddenly came up then take the soap and body scrub Howard. He gave the suggestion that the world is not safe, full of germs and dirt and Howard should sterilize themselves 
from world insecurity. Repeatedly mother told Howard to spell and memorize words, q-u-a-r-a-n-t-i-n-e.

Age Howard is still nine years old at the time it was included into the latency period (the time period is still hidden sexuality. The latent period lasts from the age of four years until puberty. Freud (in Milner, 1982: 115) said;

"During the latency period, children learn to love other people who helped him overcome the innate anxiety and give satisfaction to the various needs; and love is formed on the basis of a model relationship with her mother during the period of breastfeeding and continuation. Maybe people will refuse to identify feelings of tenderness and more children in the care of people with sexual love. The relationship between the child and the person caring for the child is a source of stimulation and sexual satisfaction continuous headed from erogenous area. Even more so when served him up (usually the mother) shows the feelings that arise from her own sexual life, such as the arms, swing, and considered purely as sexual objects. Perhaps a mother would be surprised to hear that he raised his sexual pulse through intimacy and determine the intensity of sexual pulse the future.

Based on Freud's statement above, it is important that we can pull out of this film is that the latency period of Howard little affected by his mother's love excessive influence in his life in the future. Her mother helped her cope with anxiety and give satisfaction to the various needs, one of which can be seen in the shower scene. Treatment of the mother makes Howard feels he and his mother is an integral part. The impact of this relationship too tightly will affect psychiatric Howard when he grows up.

\section{Fear Overload against germs and Dirt (Phobia)}

Doctrine and dogma are given by his mother when he was entering the latency period (as described above) has formed a mature personality Howard Hughes became a perfectionist in terms of cleanliness. This perfection makes he 
tends to make a phobia symptom against dirt. He always brought soap wherever he went and always wash hands after shaking hands with someone, especially someone he hated. Here is the scene when she was in the bathroom after shaking hands with his business rival.

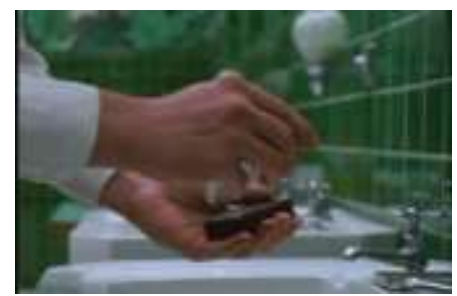

1

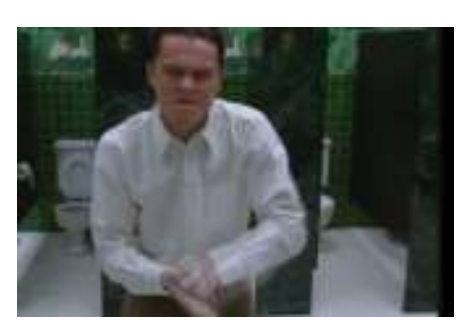

3

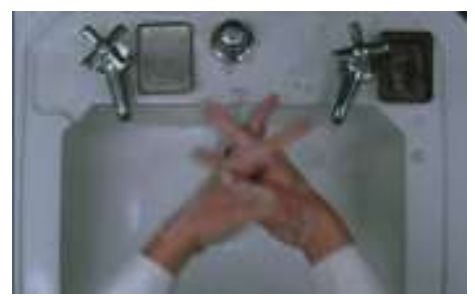

2

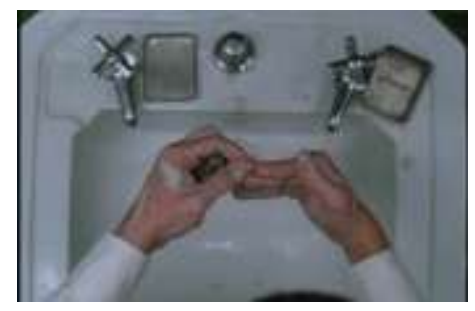

4

(Scene in the minutes 01:30:45)

The picture above is the sequence of events that occur in the scene when the Howard had done shake hands with rival business. Howard was disgusted and felt his arms full of bacteria and germs that are transmitted by the rival business. Then he stepped into the toilet and wash their hands with soap same time soap whose mother made him a bath in childhood. The first image shows the soap highlighted in extreme close-up, as if to demonstrate to the audience that the soap that Howard used is exactly the same as the mother used soap when bathing him. The second picture shows the hand movements Howard in brushing and rid it of germs. With the movement very quickly and taken extreme close up. The third image shows the facial expression Howard from behind the mirror that look of disgust as he considers that his hand had been contaminated with germs and taken close up. The fourth picture shows his bloody hand because scrubbing soap too hard. 
The Shoot of the scene is extreme close-up. It is because these scenes ask the audience about the behavior of the hero, the Howard Hughes Excessive fear of germs and disease. This scene makes it clear that there is a mental illness contracted by Howard Hughes, the phobia of germs and bacteria. It cannot be separated from the role of a mother who formed it since little Howard.

Phobia of germs and bacteria are shown in a scene when Howard and girlfriend who live with him decided to separate. Howard then burns all the clothes that he had included the time that he was using. He considers these clothes have been contaminated with germs and bacteria former liar lover.

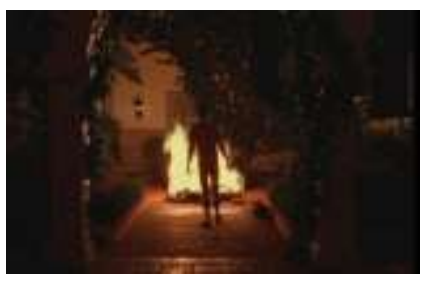

minutes 50:45

(The scene when he burned his clothes, including that he was wearing)

\section{Delusion into Reality}

Howard Hughes a millionaire and a very successful young businessman. He was obsessed with airplanes and movies. He is even willing to spend the entire property and assets which he kept to make a film the most expensive at the time and establish a national airline company. He also did not hesitate to fire and drop anyone who opposed his wishes. It turned out that all of his obsessions are the realization of a promise to convey to his mother. In the last scene of the film, when Howard achieved his dream is to have a national airline company, he returned to remember the occasion when he was talking to his mother about The Way of the Future (future). 

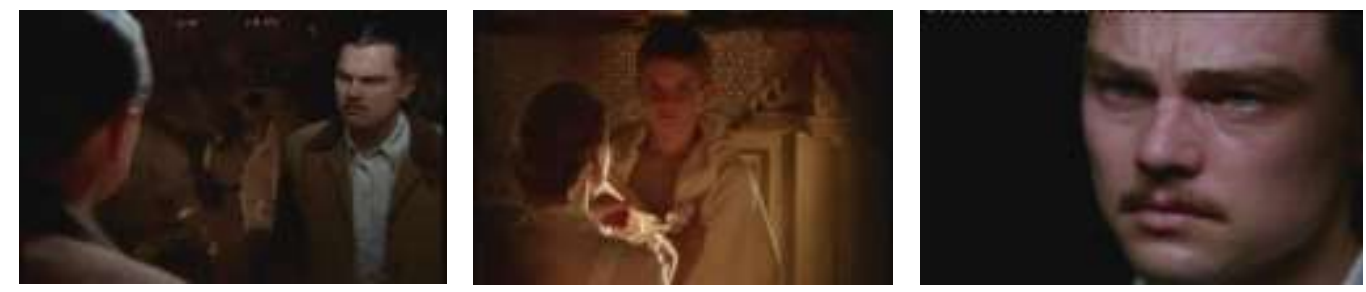

(Film the final scene.)

The picture above is the final scene in the film The Aviator's. This scene occurs when Howard was in the bathroom and looked in the mirror. He saw a small figure of Howard who was talking with her mother about the desires and ideals have its own aircraft carrier, making the most expensive film ever, and became a wealthy man. All that has been successfully he gained. Ideals and desires in childhood which he delivered before his mother had been repressed into the unconscious itself that makes Howard became obsessed by his dream and trying to realize it.

The success gained Howard is not necessarily a direct easily as he gained. He had to isolate himself due to bankruptcy. In isolation it, Howard did not eat anything and do not wear any cloth. He languished in the studio theater and he woke up alone without meeting anyone. He isolated himself because he considered what was on the outside of the studio theaters are germs and bacteria, including rival business.

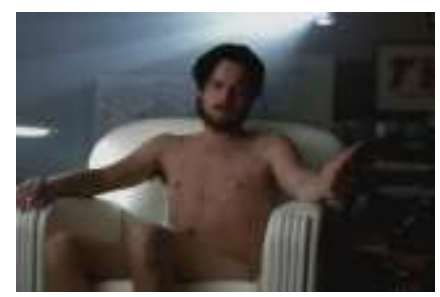

(The scene when Howard isolated himself)

Minutes 43:40

In these scenes he was reciting the word quarantine he always spoke when he is experiencing anxiety. We can say that the word quarantine reminds Howard would be his mother (his mother who introduced the word). The word quarantine 
can replace the role of a mother because she can overcome anxiety the self of Howard.

\section{Howard towards The Milk}

Howard is very interested in the milk. He did not want to drink anything but milk. When he was in isolation himself, he did not eat or drink anything but milk.

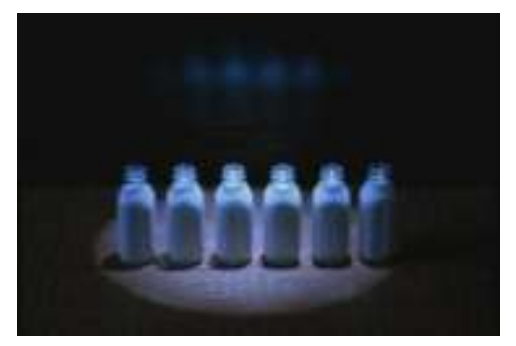

(The scene when the Howard exile, he did not eat or drink anything but milk) Minutes 45:55

Milk and mother are very close relation. Only a mother is able to produce the best milk for her child. Milk and mother are things that cannot be separated. According to Freud (in Miller, 112),

"... The initial activity, an important and essential for a child's life is sucking the mother's milk or anything else in his place. Lips children play a role as a regional erogenous and stimulation induced by impulse or pressure water warm milk induce pleasure ...)"

From the above statement, we can conclude that the interest in Howard to milk because milk is the only thing that can remind him of his mother. Her mother was the first person who gave pleasure and gives satisfaction through breast milk. As Freud said above that the encouragement or insistence warm milk causes pleasure. Thus the reason Howard enjoys milk because milk is able to cope with anxiety and is the first pleasure given by a mother he cannot forget until he was an adult because of his great love for her mother. 


\section{Compulsion inside Howard}

Compulsion is an impulse or desire that is not deliberately to do something repeatedly with a specific purpose. Somebody do something over and over again is to reduce the anxiety that strikes his mind. Compulsion is relate to the action (David Sue, et al.: 1986). In this film, The Aviator, Howard Hughes character has traits that suffer from a compulsion. Howard imaginary childhood was delivered him because his mother had made him ambitious in realizing it. He even became a very daring, did not afraid of anything and even dare to get rid of anything that is a hindrance and obstacles in realizing his desire. It makes Howard as a fear of failure. Howard is very often feeling anxiety and excessive fear. He demanded everything went smoothly and perfectly.

Howard anxiety and fear of failure make it become a compulsion. Howard often repeated sentences he spoke to someone when anxiety began attack him. The sentences out without his knowing it and he could not control. Howard must muzzle himself to avoid repeating the same words as he was not able to control the release of these words. As seen in the scene below;

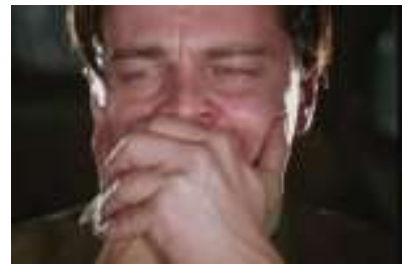

1

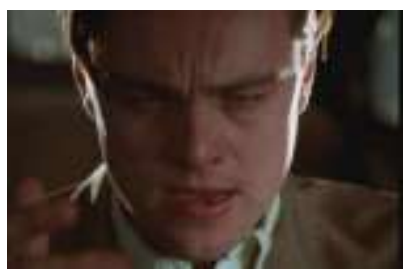

2

Minutes 80: 40

(the scene at the time of Howard Hughes cannot control the words he repeated continuously

Both of these drawings are pieces of the scene when the Howard constantly repeating what she said. The first images taken in close-up shows how ultimately Howard who is unable to control the words forced over his mouth using both hands. The second picture is still taken in close-up. The second picture shows how later expression of Howard's face changed from anxious to be a bit quieter. 
The second picture is when Howard managed to relieve the anxiety himself, by spelling out words back Quarantine had taught her when she was nine years old.

Anxiety Howard instantly lost when he began to spell the words back ever taught her, the word q-u-a-r-a-n-t-i-n-e. From here we can immediately see that the mother figure in the life of Howard is very sacred. Even when he unable to control his actions, something is imagined by the mother is able to overcome it in the words of the quarantine. Their interest in Howard against his mother was very evident in this film. Such interest can be seen from how she is able to influence the thoughts, actions, and inner conflicts that exist in Howard from childhood until he being an adult.

\section{CONCLUSION}

The Aviator (2004) this movie is so linked with the psychological analysis. The very proper psychoanalytic approach was used to analyze the film. Through observations made to the narrative elements of cinematography and the narrative of the film, it can be concluded that the role of mother figure and Howard Hughes greatly affect the growth of personality and inner conflicts experienced by Howard when he grows up. Emotional closeness and attraction to his mother Howard influence the actions and thinking Howard. The memories and the influence of her mother in the past have made an inner conflict within him. The inner conflict makes Howard experiencing various psychological problems, such as phobias and compulsion.

In closing, however, this is the early research. Hopefully, there will be continuation research regarding with this research. To discuss more complete, with some aspects that need to be under pressure and things are still a general statement can be followed with analysis and examples / illustrations are adequate. 


\section{BIBLIOGRAPHY}

Ahmeed, Sofe. Internal journal of English and literature Vol. 3(3), pp. 60-70, March 2012

Boeree DR, George C. Personality Theories e-text book. 2006

Freud S. Interpretation of Dream: 3rd edition. Translation in English: Brill A A. New York: Macmillan Company, 1913

Freud, Sigmund. Memperkenalkan Psikoanalisa (diterjemahkan K. Bertens). Jakarta: Gramedia. 1987

Milner, Max. Freud dan Interpretasi Sastra. Jakarta: Intermasa. 1982

Rahim MMA. Philosophical Ground of Western Civilization, Khairun Prokashoni. Dhaka, pp. 63-98, 2002

Safra JE (1768). The New Encyclopaedia Britannica, 15th Edition, Volume: 8, Chicago.

Scorsese, Martin, dir and Michael Mann, prod. (1982). The Aviator. Wanner Bross Picture.

Sue, David, dkk. Understanding Abnormal Behaviour. New York: Houghton Mifflin, 1986 